\title{
Corela
}

Cognition, représentation, langage

8-1| 2010

Vol. $8, n^{\circ} 1$

\section{Quel est le rôle de P2 dans une construction P1 for} P2?

Michaël Vallée

\section{OpenEdition}

Journals

Édition électronique

URL : http://journals.openedition.org/corela/857

DOI : $10.4000 /$ corela.857

ISSN : 1638-573X

Éditeur

Cercle linguistique du Centre et de l'Ouest - CerLICO

Référence électronique

Michaël Vallée, "Quel est le rôle de P2 dans une construction P1 for P2 ? », Corela [En ligne], 8-1 | 2010, mis en ligne le 30 juin 2010, consulté le 30 avril 2019. URL : http://journals.openedition.org/corela/857 ; DOI : 10.4000/corela.857

Ce document a été généré automatiquement le 30 avril 2019

\section{(c) (i) (2)(2)}

Corela - cognition, représentation, langage est mis à disposition selon les termes de la licence Creative Commons Attribution - Pas d'Utilisation Commerciale - Partage dans les Mêmes Conditions 4.0 International. 


\title{
Quel est le rôle de P2 dans une construction P1 for P2?
}

\author{
Michaël Vallée
}

\section{Introduction}

1 Les analyses sur for portent généralement sur l'appartenance du connecteur aux conjonctions de coordination ou de subordination. Cette question, d'ailleurs, ne semble pas totalement tranchée. Une autre orientation dans la recherche sur for, en tant que conjonction, s'articule autour du rôle de l'élément qui suit ce dernier, comme notamment de savoir comment le caractériser linguistiquement.

2 C'est dans cette optique que nous souhaitons proposer cette étude à partir d'un corpus composé d'exemples en anglais contemporain écrit, principalement tirés de la littérature enfantine. La fréquence d'apparition du connecteur y est, en effet, plus élevée que dans les autres genres littéraires. En revanche, à l'oral, for en tant que conjonction est très faiblement représentée (nous n'avons relevé que 2 occurrences sur un échantillon de deux textes du corpus électronique London-Lund composés de 135000 mots).

Ce travail fait ainsi suite à plusieurs travaux que nous avons menés sur le connecteur ${ }^{1}$. Nous souhaitons les prolonger en étudiant le rôle de P2 dans une structure de type P1 for $\mathrm{P} 2{ }^{2}$.

4 Nous porterons, tout d'abord, une attention particulière aux conclusions de quelques linguistes au sujet de P2 pour ensuite voir s'il est possible de les compléter. Enfin, nous terminerons notre étude en insistant sur le rôle de P2 par rapport à P1 dans une construction de type P1 for P2. 


\section{Considérations linguistiques au sujet de la proposition P2}

Il est possible de trouver différentes caractérisations du rôle de P2 dans une structure de type P1 for P2.

Parmi ces dernières, l'idée de cause est avancée. C'est notamment le cas pour Mélis qui affirme que :

«Parmi ses différents emplois, FOR peut introduire la cause d'un état de fait dans son rôle de coordonnant $»^{3}$.

L'auteur conclut ses observations sur for en précisant que :

«Le coordonnant FOR introduit un rapport causal dans les cas où la représentation

ne repose sur aucun préconstruit ».

Cette idée de rapport causal est également présente chez Wyld qui souligne que :

"Quant au cas de FOR, connecteur également ressenti comme porteur d'une nuance polémique quoique d'un type moins "appuyé » que dans le cas de SINCE, nous ne pensons pas que son analyse puisse se faire exactement de la même manière, bien que ce subordonnant soit à associer, comme SINCE et AS, à une connexion causale impliquant une relation d'entraînement préconstruite. $»^{4}$

Il est possible de remarquer que bien que les auteurs semblent partager le même point de vue concernant le rôle de P2, leur argumentation diverge quand il s'agit de considérer quand ce rapport apparait. Pour Mélis, «FOR introduit un rapport causal dans les cas où la représentation ne repose sur aucun préconstruit » alors que Wyld considère qu'il exprime une relation causale "impliquant une relation d'entraînement préconstruite». Ce commentaire est intéressant mais il semble nécessaire de s'interroger sur la relation causale qui serait impliquée par for. En effet, si l'on admet que le connecteur introduit ce type de relation, il devrait pouvoir fonctionner comme because et devrait pouvoir ainsi introduire un contenu propositionnel interrogé par why? Toutefois, la manipulation semble très difficile à réaliser comme le montrent les exemples suivants :

1. One day, when she found Frank preoccupied, he confessed that he had been strongly advised to leave England, and had refused, at any rate, for the present.

"But why not go, dear?" she urged. "You must do anything to get better."

“*For I don't want to leave you," he confessed.

En revanche, il est tout à fait possible de trouver because. C'est d'ailleurs le marqueur que l'on trouve dans l'exemple :

2. One day, when she found Frank preoccupied, he confessed that he had been strongly advised to leave England, and had refused, at any rate, for the present.

"But why not go, dear?" she urged. "You must do anything to get better."

"Because I don't want to leave you," he confessed.

(Corpus Lob, P17 59)

Cet autre exemple permet également d'illustrer le même propos :

3. Why are you so happy?

*For / Because.

7 Ces deux exemples montrent que for ne peut pas répondre à une question en why alors que because est non seulement en mesure de le faire (même seul) mais il est surtout le seul à remplir ce rôles. Par conséquent, il semble difficile de conclure que for introduit une cause ou un rapport causal. Il est donc nécessaire de prolonger la réflexion afin de comprendre le rôle de P2 par rapport à P1. 
8 La deuxième caractérisation que l'on peut trouver au sujet de P2 se trouve notamment défendue par Deléchelle. Il précise que l'élément introduit par le connecteur peut être associé au concept de justification comme l'indique la citation suivante :

«En résumé, dans les différents cas étudiés jusqu'ici, for q représente l'argument permettant de justifier (l'énonciation de) $p$ : qu'il s'agisse du fait même d'énoncer $p$ (question, ordre, requête, suggestion) ou l'un de ses termes, des diverses opérations portant sur la validité de cette prédication, ou encore de la motivation d'une action, d'une décision, d'un affect. » [...].

«Malgré ses limites, le concept de justification rend assez bien compte de l'opération sous-jacente ${ }^{6}$

9 Le concept de justification présenté par l'auteur paraît très intéressant. Il permet de signaler un ordre dans la construction des deux propositions et d'envisager une perspective différente des auteurs précédemment cités. Ainsi, si P2 vient, selon Deléchelle, justifier P1, on peut alors en déduire que P2 est construite après la proposition précédant le marqueur et qu'elle n'existe que parce que P1 a été énoncée.

Cependant, il nous semble que cette réflexion mériterait d'être prolongée en essayant de comprendre ce que recouvre ce concept et de voir comment il est possible de le décrire en termes d'opérations.

11 Enfin, une autre caractérisation est développée par De Cola qui suggère que P2 doit être envisagée comme annexe ou non-nécessaire, comme en témoigne la citation suivante :

«C'est que le repère que constitue l'énoncé q est marqué comme annexe, c'est-à-

dire a priori non nécessaire. [...]. »

L'auteur précise également les éléments suivants au sujet de P2:

"Avec for, l'énoncé repère est toujours "supplémentaire", il est pris comme illustration possible, à valeur d'exemple. $»^{8}$

Les deux citations semblent montrer que P2 n'est pas un élément obligatoire dans une construction de type P1 for P2, comme en témoigne la caractérisation «d'illustration possible, à valeur d'exemple». Cette analyse laisse penser que, selon l'auteur, cette proposition est optionnelle, non obligatoire. Faut-il, alors, considérer que P2 n'a pas de rôle véritable dans une structure P1 for P2 ?9 On pourrait être tenté de le penser si l'on s'en tient à l'argumentation de Wood lorsqu'il affirme que :

13 "For differs from the other (subordinating) conjunctions considered previously in that it introduces the reason as it were gratuitous, and by implication relegates it to a position of relative unimportance." 10

14 Si l'on admet, avec l'auteur, que la proposition introduite par for se trouve être reléguée "to a position of relative unimportance", il devrait être possible de changer l'ordre des propositions sans changer le sens de la structure P1 for P2 comme dans ce qui suit :

4. What I should have done had all gone well I do not know. Probably I should have told the whole story to the doctor, for I was in mortal fear lest the captain should repent of his confessions and make an end of me.

(R.L. Stevenson, Treasure Island, 26)

4a. What I should have done had all gone well I do not know. * For I was in mortal fear lest the captain should repent of his confessions and make an end of me, probably I should have told the whole story to the doctor.

15 Force est de constater que ce déplacement ne fonctionne pas. On peut alors supposer que si P2 ne peut pas être déplacée, c'est parce qu'elle joue un rôle particulier avec cette position dans la structure P1 for P2. On peut d'ailleurs appuyer cette supposition étant 
donné que lorsque P2 est déplacée, comme en 4a, on essaie de rattacher la proposition introduite par for à ce qui précède. Nous reviendrons sur ce point.

De la même manière, la manipulation ne fonctionne pas non plus dans l'exemple qui suit :

5. She lived and was given a name. Helva. For her first three vegetable months she waved her crabbed claws, kicked weakly with her clubbed feet and enjoyed the usual routine of the infant. She was not alone, for there were three other such children in the big city's special nursery.

(Corpus, Brown, M05 0030 5)

5a. * For there were three other such children in the big city's special nursery, she was not alone.

Cet ordre incite de nouveau à rattacher la proposition introduite par le connecteur à ce qui précède. Toutefois, le lien sémantique paraît difficile à établir. Les tests ${ }^{11}$, par ailleurs, montrent qu'il n'est pas possible de mettre la proposition P2 avant P1.

Il semble alors nécessaire de prolonger la réflexion afin de comprendre le rôle de P2 par rapport à P1 dans une structure de P1 for P2.

\section{Quel est le rôle de la proposition P2 dans P1 for P2?}

18 Essayons tout d'abord de vérifier l'hypothèse selon laquelle cette proposition doit être considérée comme une illustration ou comme un élément non obligatoire à la suite de for.

\section{La proposition P2 joue-t-elle un rôle secondaire?}

19 Si on répond par la positive à cette question, en adoptant ainsi la position de De Cola, ceci signifie théoriquement que la proposition P2 peut faire l'objet d'un effacement sans avoir aucune incidence sur la cohérence de l'ensemble dans lequel s'insère P1. Toutefois, cela implique également que si un seul exemple est difficilement recevable ou tout simplement irrecevable du point de vue $\mathrm{du} \operatorname{sens}^{12}$, on devra en conclure que la caractérisation de $\mathrm{P} 2$, en tant qu'illustration, ne permet pas de rendre complètement compte du rôle de cette dernière par rapport à $\mathrm{P} 1$.

L'hypothèse de l'effacement semble fonctionner au regard des deux exemples suivants. Il est possible de supprimer for P2 dans ces énoncés et ne garder que P1. Cette relation prédicative parait se suffire à elle-même pour fonctionner et être acceptable :

6. During the rest of that day there was no other adventure to mar the peace of their journey. Once, indeed, the Tin Woodman stepped upon a beetle that was crawling along the road, and killed the poor little thing. This made the Tin Woodman very unhappy, for he was always careful not to hurt any living creature; and as he walked he wept several tears of sorrow and regret.

(L. Frank Baum, The Wonderful Wizard of $\mathrm{Oz}, 45$ )

6a. During the rest of that day there was no other adventure to mar the peace of their journey. Once, indeed, the Tin Woodman stepped upon a beetle that was crawling along the road, and killed the poor little thing. This made the Tin Woodman very unhappy $[\varnothing]$ and as he walked he wept several tears of sorrow and regret.

7. (suite). These tears ran slowly down his face and over the hinges of his jaw, and there they rusted. When Dorothy presently asked him a question the Tin Woodman could not open his mouth, for his jaws were tightly rusted together. He became greatly frightened at this and made many motions to Dorothy to relieve him, but 
could not understand.

(L. Frank Baum, The Wonderful Wizard of $\mathrm{Oz}, 45$ )

7a. (suite). These tears ran slowly down his face and over the hinges of his jaw, and there they rusted. When Dorothy presently asked him a question the Tin Woodman could not open his mouth [ø]. He became greatly frightened at this and made many motions to Dorothy to relieve him, but could not understand.

21 les deux cas, même s'il est possible de s'interroger sur les raisons de la tristesse du « Tin Woodman " et sur l'incapacité décrite. Au début de son voyage, il est en effet décrit comme pouvant répondre à des questions sans difficulté. Toutefois, la structuration du récit n'est pas remise en cause par ces effacements.

Les exemples précédents semblent donc corroborer l'hypothèse du caractère nonnécessaire de $\mathrm{P} 2$.

Toutefois, il est des exemples où l'interprétation de l'enchaînement inter-propositionnel est plus difficile à envisager comme en témoignent les énoncés suivants :

8. At first my mouth and throat were parched, and my strength ebbed sensibly. I sat about in the darkness of the scullery, in a state of despondent wretchedness. My mind ran on eating. I thought I had become deaf, for the noises of movement I had been accustomed to hear from the pit had ceased absolutely. I did not feel strong enough to crawl noiselessly to the peephole, or I would have gone there.

(H. G. Wells, The War of the Worlds, 150)

?8a. At first my mouth and throat were parched, and my strength ebbed sensibly. I sat about in the darkness of the scullery, in a state of despondent wretchedness. My mind ran on eating. I thought I had become deaf, [...]. I did not feel strong enough to crawl noiselessly to the peephole, or I would have gone there.

9. One night there flew over the city a little Swallow. His friends had gone away to Egypt six weeks before, but he had stayed behind, for he was in love with the most beautiful Reed. He had met her early in the spring as he was flying down the river after a big yellow moth, and had been so attracted by her slender waist that he had stopped to talk to her.

(O. Wilde, The Happy Prince, 154)

*9a. One night there flew over the city a little Swallow. His friends had gone away to Egypt six weeks before, but he had stayed behind [...]. He had met her early in the spring as he was flying down the river after a big yellow moth, and had been so attracted by her slender waist that he had stopped to talk to her.

La suppression de $\mathrm{P} 2$ est délicate en 8a et très problématique en $9 \mathrm{a}$. Ces effacements ont pour conséquence soit de réduire, soit de désorganiser la cohérence du récit comme on l'observe notamment en 9a.

Ainsi, au regard de ces deux exemples, il nous semble délicat de conclure que P2 puisse être seulement considéré comme une illustration ou comme un élément secondaire.

Il paraît alors intéressant d'envisager une autre perspective de recherche qui permette de prolonger l'analyse du connecteur, qui se révèle nécessaire afin de comprendre le rôle de P2. A cet effet, nous nous proposons d'effectuer une étude sur l'organisation de cette proposition complétée par une analyse en lien avec la Théorie des Opérations Prédicatives et Enonciatives afin de voir s'il est possible d'envisager le fonctionnement de P2 sous un autre angle.

\section{La structuration de P2}

L'analyse de P2 fait ressortir les constructions suivantes ${ }^{13}$. 
a) verbes d'état ${ }^{14}$ :

10. The "golden jubilee" meeting of Lincoln W.E.A. branch forged a new interesting link in its history.

The branch has survived two world wars, and battled its way successfully through the Great Depression. Now it has gone full circle for, after the austerities of the first war, the grim despondency of the Depression, and the rationed utilities of the second war it has met to consider "The Affluent Society."

But, possibly even more interesting than this, was the fact that the speaker was Mrs. Mary Stocks, well-known as a member of the B.B.C. Brains Trust and radio programme "Any Questions?"

Though she had paid only brief "passing through" visits to the city in the past, Lincoln is not entirely unknown to Mrs. Stocks, for she is the sister-in-law of Miss Helen Stocks who was the first resident tutor of the branch.

(Corpus Lob, B22 83)

b) procès construits comme validés avec l'aspect grammatical qui leur est associé ${ }^{15}$.

11. There never was a Crimean War: the whole story must be the invention of some satirist frantic with hatred for warfare and aristocracy. So at least I felt more strongly than ever when reading the book under review. Not that Mr. Hibbert denounces our Government for feebly drifting into so unnecessary a war: his account of its origins is restricted to three colourless pages, for he writes as a military historian concerned only with the conduct of the campaign.

(Corpus Lob, C08 12)

c) renvoi à la notion :

12. Even the tiger runs and hides when little Tabaqui goes mad, for madness is the most disgraceful thing that can overtake a wild creature.

(R. Kipling, The Jungle Books, 12)

d) intensifieurs ou marqueurs de comparaison:

13. She, on her part, promised to marry me as soon as I could earn enough money to build a better house for her; so I set to work harder than ever. But the girl lived with an old woman who did not want her to marry anyone, for she was so lazy she wished the girl to remain with her and do the cooking and the housework

(L. Frank Baum, The Wonderful Wizard of $\mathrm{Oz}, 38$ )

e) construction de re-assertion

14. This was the highlight of the review of East-West relations in the meeting between the President and the Prime Minister.

The talks lasted for three hours. This was a surprise, for they had only been scheduled to last two hours.

(Corpus Lob, A28 212)

f) assertion fictive

15. 'Glinda is a good witch, isn't she?' asked the child.

'The Quadlings think she is good,' said the soldier, 'and she is kind to everyone. I have heard that Glinda is a beautiful woman, who knows how to keep young in spite of the many years she lived.'

'How can I get to her castle?' asked Dorothy.

'The road is straight to the South,' he answered, 'but it is said to be full of dangers to travellers. There are wild beasts in the woods, and a race of queer men who do not like strangers to cross their country. For this reason none of the Quadlings ever come to the Emerald City.'

The soldier then left them and the Scarecrow said:

'It seems, in spite of dangers, that the best thing Dorothy can do is to travel to the Land of the South and ask Glinda to help her. For, of course, if Dorothy stays here she will never get back to Kansas.'

(L. Frank Baum, The Wonderful Wizard of Oz, 129)

Ces différents éléments permettent de mettre en évidence une délimitation qualitative ${ }^{16}$ des éléments en jeu dans P2. 
en est une illustration. On observe la construction d'un état qui, par définition, n'est ni borné à gauche ni borné à droite. La copule be marque la construction d'un domaine homogène et répond à la définition des prédicats ayant un fonctionnement de type compact que Franckel et Paillard décrivent ainsi :

«Il s'agit d'une configuration où une délimitation qualitative ne se trouve relayée par aucune délimitation Qnt. Il n'y a pas construction d'occurrence. L'actualisation d'un procès compact passe par sa mise en relation à un support externe [...]. Celle-ci permet son actualisation sans pour autant qu'en résulte une délimitation Qnt. . ${ }^{17}$

On en déduit que la délimitation qualitative de la copule be est également mise en évidence pour l'opération d'identification dont elle est la trace et que Culioli définit de la manière suivante :

«Par l'identification, le sujet pose qu'une occurrence $a$ est une occurrence de la notion $A$. [...], il importe de marquer avec force qu'il s'agit là de l'opération fondamentale de mise en relation. Sans identification, on ne peut construire ni termes, ni relations entre termes, ni relations de repérages. [...].

L'identification peut être conçue de deux façons: soit comme l'identification de telle occurrence d'une notion à une représentation typique, ce qui nous donne l'indiscernabilité qualitative, soit comme l'abolition de la distance qui sépare des occurrences, chacune déjà identifiée, ce qui produit une identification qualitative à travers l'altérité situationnelle. $»^{18}$

Si l'on reprend l'exemple 10 , on constate que l'on a affaire au premier cas décrit pour lequel l'énonciateur identifie un élément repéré à un élément repère montrant ainsi que le premier partage les propriétés du second.

Cette opération d'identification marque ainsi la mise en place, en plus des autres propriétés déjà construites, de la propriété de «sister-in-law of Miss Helen Stocks » par rapport à « she ».

31 On assiste ainsi à la construction d'un domaine homogène dans la mesure où le procès n'est pas borné. Il s'agit d'un domaine structuré dans lequel seul l'intérieur est privilégié.

La construction suivante permet également de mettre en avant cette idée. Le prédicat, qui est associé au présent simple, construit un procès validé et, par conséquent, un état comme le suggère le commentaire de Bouscaren et Chuquet:

«Le présent simple est en anglais un temps qui marque que le contenu de sens correspondant au prédicat est validé (c'est-à-dire vérifié) pour le sujet de l'énoncé.

L'énonciateur se contente de valider la relation entre le sujet et le prédicat. Il présente ce qu'il dit comme une vérité en soi, indépendante de tout point de vue particulier. C'est ce que nous appelons souvent «renvoi à la notion [...]» dans la mesure où il s'agit d'un minimum de déterminations intervenant sur la relation prédicative. $»^{19}$

Il s'agit, dans ce cas, de n'envisager que la délimitation qualitative du procès. Ce dernier construit un domaine structuré et homogène dont seul l'intérieur est considéré.

La délimitation qualitative apparaît également avec la distribution suivante. Dans l'énoncé 12 , l'absence d'article devant le nom construit un renvoi à la notion. Il renvoie à la structuration d'un domaine notionnel dont seul l'intérieur est considéré. On envisage, dans cet exemple, la notion /madness/ avec toutes les propriétés qui la caractérisent.

L'exemple 13 illustre lui aussi cette même idée. On note également la présence de so à la suite de be. L'analyse de cet exemple peut se faire de la manière suivante.

La notion en jeu dans cet énoncé, à savoir/lazy/, permet la construction d'un domaine notionnel structuré entre un intérieur, un extérieur et une frontière. A partir de cette 
notion, on peut définir un intérieur : "lazy », une frontière : "not really lazy but not really not lazy " et un extérieur: "not lazy». Ici, la notion /lazy/ est identifiée au personnage «she » par l'intermédiaire de la copule be. Cette identification implique la construction d'une propriété centrée < be lazy > identifiée à ce personnage.

Vient s'ajouter à ce qui vient d'être mentionné, une autre opération énonciative qui consiste à faire jouer sur cette propriété le marqueur so de manière à mettre en valeur un degré très élevé de "laziness». Il est, d'ailleurs, intéressant de noter que l'on se rapproche, avec ce type de construction, du haut degré défini par Culioli ${ }^{20}$, ce qui montre que seule la délimitation qualitative est prise en compte dans cette construction.

La délimitation qualitative se manifeste également dans l'énoncé 14 . Ce dernier se caractérise par une opération de re-assertion ou d'identification par rapport à une assertion préconstruite comme le montre la présence de l'aspect " perfect » au passé et par « only » dans « they had only been scheduled to last two hours ».

Une des propriétés essentielles du "past-perfect» se manifeste par sa valeur de bilan repéré par rapport à une situation en rupture avec la situation d'énonciation origine. Ce qui signifie que, par rapport à la situation construite avec les différents prédicats associés au prétérit tels que be ou last et qui sont en rupture par rapport à la situation d'origine, la relation «they had been scheduled to last two hours " est repérée par rapport à la situation construite avec les prédicats associés au prétérit. Par conséquent, la relation $<$ they [the talks] - last - two hours > était le cas dans une situation antérieure à cette situation construite. De plus, cette re-assertion ou identification à une assertion préconstruite est renforcée par only. Ce marqueur indique que seule la relation précédemment citée devait être considérée comme étant le cas ; toutes les autres durées associées au sujet et mises en relation avec ce prédicat étaient, par conséquent, de mauvaises valeurs. Par ailleurs, il faut ajouter que only intervient justement parce que "This was a surprise " a été construit. En effet, la relation «this - be - a surprise» marque un jugement sur la relation « The talks lasted for three hours » comme étant une mauvaise valeur pour l'énonciateur par rapport à une valeur attendue. Cette valeur attendue étant précisément introduite par for et renforcée par only dans le sens où ce dernier montre qu'une valeur et une seule avait été déjà construite pour la validation de la relation concernant la durée des « talks ».

Par conséquent, nous voyons que la délimitation qualitative est privilégiée dans la mesure où on a affaire à la construction d'un domaine structuré et centré sur l'intérieur.

Enfin, le dernier énoncé permet également de mettre en évidence une délimitation qualitative qui est illustrée par la présence d'une assertion fictive ${ }^{21}$.

Avant de procéder à l'explication de cet exemple, essayons de voir ce que recouvre le concept d'assertion fictive dans la théorie des opérations prédicatives et énonciatives.

Une assertion fictive témoigne, de la part de l'énonciateur, d'une prise de distance par rapport à sa relation tout en présentant une valeur souhaitée / supposée pour la validation. Il y a donc engagement subjectif de l'énonciateur dans la mesure où il propose une valeur (soit p, soit p') comme « outil de travail ». Cependant, même si une valeur est posée, on ne peut exclure son complémentaire pour la validation de la relation. L'énonciateur construit donc une situation fictive tout en s'engageant pour une valeur. Ainsi, à partir de Sito, l'énonciateur construit une situation origine fictive Sito ${ }^{1}$ marquée par la présence de if $\mathrm{P}$ qui va permettre à l'aide de l'apodose (la proposition $\mathrm{Q}$ ) de viser la validation de la relation prédicative. L'énonciateur pose, avec cette nouvelle situation, 
une relation prédicative validable au double sens du terme: elle est en mesure d'être validée et elle peut ou non être validée.

Cette distribution illustre, elle-aussi, la mise en place d'une délimitation qualitative, dans la mesure où il s'agit de poser une valeur par l'intermédiaire de if $\mathrm{P}$. On a également affaire à la construction d'une visée (dans la proposition $\mathrm{Q}$ ) afin de privilégier une valeur, que Franckel et Lebaud décrivent ainsi :

«Nous avons vu précédemment que toute occurrence d'une notion est située relativement à l'une des zones I, ou E [...]. Mais ce rattachement peut soit être effectif soit envisagé. Dans ce dernier cas, l'occurrence est construite à partir d'une position décrochée, hors domaine qui aboutit soit à I, soit à E. Cette position correspond à IE [...].

Citons ici A. Culioli (1989) lui-même: "Le graphe prototypique est celui de la bifurcation : à la pointe, on n'est ni en $\mathrm{E}$ ni en $\mathrm{I}$, mais de la pointe I et $\mathrm{E}$ sont accessibles. Si l'on note IE (E renforcé) la position décrochée, on voit que l'on peut tracer deux chemins, l'un vers I, l'autre vers E... ».

On a ainsi le graphe suivant :

I E

IE

Ces trois pôles ne coexistent pas simultanément: être en I exclut d'être en E et réciproquement. Par contre, être en IE n'exclut ni I ni E, mais mène potentiellement à I ou à $E[. .$.$] .$

[...].

Tracer un chemin signifie représenter 1 qu'il y a un hiatus entre la position de départ et la zone d'arrivée ; 2 que ce hiatus peut être comblé ; 3 que l'on peut effectuer sur la bifurcation diverses opérations : conserver les deux chemins, en éliminer un, pondérer un chemin par rapport à l'autre, etc.

C'est précisément à cette pondération que correspond la visée. Cette pondération est due à une valuation: la visée correspond à la sélection de l'une des zones (a priori I) comme bonne valeur. $»^{22}$

Ce concept met donc en avant une sélection. Autrement dit, l'énonciateur, dans les assertions fictives, fait comme si une valeur, soit $\mathrm{p}$ soit $\mathrm{p}$, est le cas au moment de la situation de l'énoncéé ${ }^{3}$.

Par conséquent, la délimitation qualitative l'emporte sur la délimitation quantitative dans les assertions fictives.

Si l'on revient à l'exemple 15, ci-dessus, on remarque que l'énonciateur se positionne par rapport à une valeur, à savoir $\mathrm{p}:$ « if Dorothy stays here ». On note, par ailleurs, que cette sélection, puisqu'elle pose une valeur comme étant le cas, est construite comme stabilisée (validée), comme en témoigne le prédicat associé au présent simple, i.e. à l'aspect aoristique. Cette stabilité énonciative permet le renvoi, avec le marqueur if, à une situation origine fictive à partir de laquelle la validation de l'autre relation est envisagée. 24

Par voie de conséquence, cette structure participe d'une valuation de la part de l'énonciateur et, de ce fait, seule la délimitation qualitative de cette relation est privilégiée.

On peut donc conclure que l'analyse énonciative des différentes constructions dans P2 révèle la construction d'une délimitation qualitative. Toutefois, il reste à comprendre pourquoi cette caractéristique apparaît dans cette proposition et aussi à déterminer son rôle par rapport au fonctionnement de P1. 


\section{Rôle de P2 par rapport à P1}

\subsection{Rappel du fonctionnement de P1}

50

d'autres travaux ${ }^{25}$, nous proposons un résumé succinct de son fonctionnement.

51 L'analyse des propriétés de cette proposition a permis de montrer que P1 est toujours la trace d'une altérité ou d'une hétérogénéité énonciative. En d'autres termes, cette dernière met en évidence soit une notion dont les propriétés, qui sont généralement admises par n'importe quel énonciateur, sont déconstruites, soit une relation qui n'est pas validée, soit d'une dissociation entre les origines énonciative et assertive pour ne citer que ces quelques exemples.

Nous ne donnerons, afin d'illustrer notre propos, que deux énoncés illustrant les deux premiers $\operatorname{cas}^{26}$.

16. '[...]. I am the Guardian of the Gates, and since you demand to see the Great Oz I must take you to his place. But first you must put on the spectacles.'

'Why?' asked Dorothy.

'Because if you did not wear spectacles the brightness and the glory of the Emerald City would blind you. Even those who live in the City must wear spectacles night and day. They are all locked on, for $\mathrm{Oz}$ so ordered it when the City was first built, and I have the only key that will unlock them.'

(L. Frank Baum, The Wonderful Wizard of Oz, 70)

17. I observed the doctor sniffing and sniffing, like someone tasting a bad egg.

"I don't know about treasure," he said, "but I'll stake my wig there's fever here."

If the conduct of the men had been alarming in the boat, it became truly threatening when they had come aboard. They lay about the deck growling together in talk. The slightest order was received with a black look and grudgingly and carelessly obeyed. Even the honest hands must have caught the infection, for there was not one man aboard to mend another.

(R.L. Stevenson, Treasure Island, 84)

L'exemple 16 offre la possibilité de souligner ce que nous avons décrit comme un décentrage notionnel. Si on définit un domaine notionnel construit à partir de la notion / spectacles/, on peut reconnaitre, en fonction des propriétés physico-culturelles qu'on leur associe, que le prédicat lock (on) ne fait pas partie des occurrences identifiables à l'intérieur de ce domaine. Or, dans l'exemple, ce prédicat est construit de manière à appartenir aux occurrences identifiables à l'intérieur du domaine. Il y a donc construction d'une altérité. On peut, par ailleurs, remarquer que le décentrage est renforcé par all qui marque une opération de parcours afin de montrer que le phénomène décrit, et, par extension, la construction du décentrage notionnel, ne souffrent aucune exception.

L'énoncé 17 met en avant un positionnement de l'énonciateur sur les chances de validation de la relation prédicative. La probabilité de validation de la relation est très forte, toutefois, comme l'atteste la construction verbale must have caught, l'énonciateur ne peut se porter garant de la validation de la relation prédicative par rapport à la situation de l'énoncé.

La proposition souligne ainsi la construction d'une altérité. En effet, le modal épistémique marque une distance entre la valeur posée et celle qui permettrait de valider la relation en $\mathrm{jeu}^{27}$. 
exemples permettent d'illustrer le fait que la construction énonciative de P1 témoigne d'une altérité énonciative. Essayons de comprendre, dans ce contexte, le rôle de P2 par rapport à P1.

\subsection{Caractérisation du rôle de $\mathrm{P} 2$ par rapport à $\mathrm{P} 1$}

Les deux exemples qui suivent permettent, nous semble-t-il, d'illustrer le fonctionnement de P2:

18. Once the Witch struck Toto a blow with her umbrella and the brave little dog flew at her and bit her leg, in return. The Witch did not bleed where she was bitten, for she was so wicked that the blood in her had dried up many years before.

(L. Frank Baum, The Wonderful Wizard of $\mathrm{Oz}, 93$ )

19. After an hour or so the light faded away, and they found themselves stumbling along in the darkness. Dorothy could not see at all, but Toto could, for some dogs see very well in the dark [...].

(L. Frank Baum, The Wonderful Wizard of $O z, 33$ )

Tout d'abord, il est possible d'observer que P1 dans l'énoncé 18 a un fonctionnement similaire à celui de l'exemple 16. En effet, si l'on construit un domaine notionnel à partir de / to be bitten /, on accorde généralement, par rapport aux propriétés physiques d'une morsure, que le prédicat «bleed» fait partie des occurrences identifiables au domaine constitué et qu'il se trouve, par conséquent, à l'intérieur de celui-ci. Or, dans cet exemple, on construit le prédicat «bleed»comme ne pouvant pas être identifié, et, par conséquent, comme ne pouvant pas être à l'intérieur du domaine considéré. De la construction de P1 découle une altérité énonciative. La proposition P2, pour sa part, est à mettre en relation avec l'exemple 13 puisqu'elle est structurée à partir d'une copule (be) et d'un intensifieur. Cette proposition construit ainsi une délimitation qualitative. Cette construction n'est pas fortuite, à notre sens ; elle est, au contraire, nécessaire.

ous semble que la présence de P2 permet, avec ses propriétés, de revenir sur la prise en charge de $\mathrm{P} 1$ et de réduire ou de compenser l'altérité énonciative de celle-ci afin de la rendre acceptable. La proposition P2 va pouvoir stabiliser une construction qui pourrait paraître instable ou problématique pour un co-énonciateur potentiel.

Cette idée se dégage également de l'énoncé 19 . On constate que le prédicat see est associé au présent simple, ce qui implique la validation du procès et aussi l'attribution d'une propriété à some dogs. Il apparaît également la construction d'une délimitation qualitative.

60 La proposition P1 illustre la caractéristique que nous avons mise en avant, à savoir une altérité énonciative qui se manifeste par la présence d'un décentrage notionnel. On prête normalement aux chats la caractéristique de voir dans l'obscurité. Or, dans le cas présent, il s'agit d'un chien et non d'un chat, à qui, on accorde certaines propriétés mais pas celle de voir la nuit. On assiste donc à la construction du décentrage de l'une des propriétés du chien en question puisque l'association du terme source « Toto » avec le prédicat « see (in the dark)» ne peut faire l'objet d'une propriété stable appliquée aux chiens par rapport aux différentes caractéristiques que l'on attribue «normalement " à cette espèce. En conséquence, cette altérité énonciative construit une instabilité pouvant créer une incompréhension ou une objection de la part d'un co-énonciateur potentiel.

61 Cette instabilité est compensée par la présence de P2 qui revient sur la prise en charge de P1 afin de réduire l'altérité présente dans la première proposition. La construction qui 
pouvait paraître problématique pour un co-énonciateur potentiel est rendue acceptable par la présence de $\mathrm{P} 2$.

Cette idée est soulignée par la description de la propriété en P2 dans l'exemple. On remarque, en effet, un quantifieur (some) qui est associé à dogs. Nous suggérons que sa présence est nécessaire, comme le montre la manipulation suivante :

19a.? After an hour or so the light faded away, and they found themselves stumbling along in the darkness. Dorothy could not see at all, but Toto could, for $\varnothing$ dogs see very well in the dark; [...].

L'article $\varnothing$ serait ici difficilement interprétable parce que l'énonciateur-narrateur interviendrait dans le récit (cf. le présent associé à see) pour signaler que tous les chiens voient la nuit, ce qui ne correspond pas aux propriétés que l'on attribue à cette espèce.

Le quantifieur permet de construire une sous-catégorie de chiens qui possèdent cette propriété d'après l'énonciateur-narrateur. Cette caractéristique étant posée, une nouvelle relation < some dogs-see-in the dark > est alors construite comme étant le cas dans P2, ce qui va permettre de revenir sur l'altérité en P1 en la rendant ainsi acceptable.

La présence de $\mathrm{P} 2$ est, par conséquent, nécessaire et la construction d'une délimitation qualitative n'est pas fortuite car elle permet de revenir sur l'altérité de P1 et rendre ainsi la structure P1 for P2 acceptable.

Nous ne pensons pas, dans ce cas, que l'on peut analyser P2 comme le fait De Cola dans les commentaires suivants :

« Cette opération [la mise en place de P2] est adressée à l'éventuel co-énonciateur qui, par erreur, ignorance ou manque de mémoire, se placerait comme pôle adverse dans l'altérité des sujets énonciateurs. $\|^{28}$

«[Il s'agit] d'accuser le co-énonciateur de mauvaise volonté ou d'ignorance, et de lui reprocher d'avoir à ajouter un argument supplémentaire, qui devrait être connu de lui. ${ }^{29}$

Nous suggérons, pour notre part, que la relation construite en P2 n'a pas pour objet d'accuser le co-énonciateur "de mauvaise volonté ou d'ignorance» mais qu'elle est nécessaire afin d'éviter une objection éventuelle de ce dernier en raison de P1. La relation posée en $\mathrm{P} 2$ est, de plus, très probablement ignorée d'un co-énonciateur potentiel puisqu'il s'agit d'une relation nouvelle, voire même inédite pour ce dernier. L'élément qui implique cependant l'acceptation de $\mathrm{P} 2$ par rapport à un co-énonciateur potentiel est la construction d'une délimitation qualitative qui permet de poser P2 comme étant le cas au moment de l'énoncé. Ainsi, cette délimitation qualitative revient sur les modalités de prise en charge de $\mathrm{P} 1$ afin de rendre l'altérité énonciative de cette dernière acceptable et rendre ainsi la structure P1 for P2 non problématique pour un co-énonciateur potentiel.

Cette analyse de $\mathrm{P} 2$ est, en effet, confirmée par les deux exemples suivants :

20. The eyes of the Happy Prince were filled with tears, and tears were running down his golden cheeks. His face was so beautiful in the moonlight that the little Swallow was filled with pity.

'Who are you?' he said.

'I am the Happy Prince.'

'Why are you weeping then?' asked the Swallow; 'you have quite drenched me.'

'When I was alive and had a human heart,' answered the statue, 'I did not know what tears were, for I lived in the palace of Sans-Souci, where sorrow is not allowed to enter.

(0. Wilde, The Happy Prince, 156)

21. "[...]. There are no mice in the air, I'm afraid, but you might catch a bat, and that's very like a mouse, you know. But do cats eat bats, I wonder?" And here Alice 
began to get rather sleepy, and went on saying to herself, in a dreamy sort of way, "Do cats eat bats? Do cats eat bats?" and sometimes, "Do bats eat cats?" for, you see, as she couldn't answer either question, it didn't much matter which way she put it.

(L. Carroll, Alice's Adventures in Wonderland, 26)

On observe en 20, dans la proposition P1, la construction d'un dialogue dont le contenu propositionnel When I was alive and had a human heart est attribuable à the statue. Cette proposition introduite par when est la proposition repère de I did not know what tears were et permet la construction de deux propriétés : < be alive > et < have a human heart > identifiées au personnage the statue et en rupture par rapport à la situation de l'énoncé : il y a construction de deux propriétés identifiées au personnage comme étant le cas à un moment révolu. Or, ceci permet également de prédiquer et de poser comme étant également le cas l'inexistence de la «connaissance des larmes» pour le personnage. Autrement dit, la construction de la localisation de la notion /larme/ relativement à the statue était impossible.

Ainsi, par rapport à la construction de deux propriétés «be alive » et " have a human heart » correspondant à deux domaines notionnels centrés qui possèdent chacun des propriétés, la localisation de la notion /tear/ est impossible. Or, la propriété décrite dans « have a human heart » ne renvoie pas à la prédication d'un « heart » quelconque mais d'un cœur qualifié de «human ». Ceci signifie que l'une des propriétés constitutives d'un " human heart» doit " permettre », lorsqu'elle est identifiée à un " animé humain » (et c'est d'ailleurs la raison pour laquelle la propriété de $<$ be alive $>$ est construite pour insister sur la différence d'état entre la période révolue et celle de l'énoncé), la localisation de "tears " par rapport à un sujet comme étant constitutive de la classe d'occurrences relatives à l'intérieur du domaine notionnel construit à partir de « human heart ». La proposition P1, dans cet énoncé, marque la construction d'un décentrage notionnel, à partir de la propriété de < have a human heart > identifiée à the statue et de la notion /tear/ qui est construite comme n'étant pas identifiée à cette propriété.

Cette opération peut impliquer une incompréhension ou une objection de la part d'un coénonciateur potentiel. Toutefois, la relation prédicative en P2 permet de revenir sur cette altérité énonciative en prédiquant une propriété, que l'on peut supposer inconnue d'un co-énonciateur, à savoir la relation < I-live in the Palace of Sans-Souci >, domaine à partir duquel il est prédiqué que l'identification de la notion/sorrow/ ne peut pas se faire. Cependant, la propriété construite en P2 permet de rendre acceptable le décentrage notionnel en P1, à l'aide de la définition de la nouvelle relation, rendant ainsi la structure P1 for P2 acceptable.

Il en va de même pour l'énoncé 21 , où plusieurs formes d'altérité énonciative apparaissent en P1. On peut tout d'abord relever une altérité qui se manifeste sous la forme d'une hétérogénéité énonciative. La suite de constructions interrogatives « Do cats eat bats? Do cats eat bats? » et « Do bats eat cats? » constitue des intrusions de discours direct dans du récit, comme le montre le prétérit associé aux différents prédicats tels que begin et go on et l'insertion de and sometimes dans " And here Alice began to get rather sleepy, and went on saying to herself, in a dreamy sort of way, "Do cats eat bats? Do cats eat bats?" and sometimes, "Do bats eat cats?" ». Ceci témoigne donc d'une distinction de plans d'énonciation en raison des différentes prises en charge. Les trois interrogations sont prises en charge par Alice alors que le récit est pris en charge par l'énonciateurnarrateur. 
71 On peut aussi noter la présence d'un décentrage notionnel marqué par l'agencement des notions de la relation prédicative $\mathrm{P} 1$. Si l'on prend les notions respectives de la dernière question posée en P1 de l'exemple 21, à savoir /cat/, /eat/ et /bat/, on conçoit que leurs propriétés primitives - et l'interaction de ces propriétés - doivent aboutir à une relation particulière entre ces notions pour former une relation prédicative acceptable. Afin de produire une question acceptable, il serait souhaitable d'avoir la notion /cat/ en tant que notion source du procès alors que /bat/ devrait être la notion but lorsque celles-ci sont mises en relation avec un prédicat comme /eat/. Or, l'ordre des notions ne correspond pas à celui que l'on attendrait en fonction de leurs propriétés physico-culturelles respectives. Cette association des notions en jeu témoigne d'une opération de décentrage notionnel dans la mesure où les valeurs référentielles de l'interrogation sont difficiles à reconstruire.

La construction de P1 est susceptible de provoquer une interrogation ou une incompréhension de la part d'un co-énonciateur potentiel. La proposition P2 met en avant une prédication qui permet de rendre acceptable l'altérité présente en P1.

Comme nous l'avons déjà souligné, il nous semble difficile de considérer que cette prédication soit connue d'un co-énonciateur potentiel. La raison de sa construction repose uniquement sur le fait qu'elle doit rendre acceptable l'altérité en P1, ce qui la rend nécessaire pour la cohérence de la narration.

Ces exemples soulignent donc le rôle et le caractère obligatoire de la proposition P2 afin de revenir sur l'altérité énonciative en P1 et de rendre ainsi acceptable la relation de P1 for P2.

\section{Conclusion}

75 Nous avons vu que la proposition P2 dans une structure de type P1 for P2 faisait l'objet de différentes considérations linguistiques. Elle illustre, selon les auteurs, une cause, une justification ou une illustration qui doit s'interpréter comme quelque chose de secondaire ou de non obligatoire.

Nous avons essayé de montrer que ces différentes analyses pouvaient être prolongées afin de déterminer la spécificité linguistique de la proposition P2. Pour cela, nous avons effectué une analyse énonciative de cette dernière qui a mis en lumière une construction spécifique. Nous avons ainsi observé qu'une délimitation qualitative apparaît, alors que la proposition P1 construit une altérité énonciative.

La propriété de P2 a permis de conclure que cette proposition était nécessaire afin de revenir sur l'altérité énonciative présente en $\mathrm{P} 1$, ayant pour effet de rendre cette dernière, ainsi que la relation P1 for P2, acceptables.

Il nous paraît donc difficile de considérer cette proposition comme une illustration avec un rôle secondaire. Son existence ainsi que son fonctionnement sont, au contraire, importants.

On peut donc en conclure que sa construction énonciative ainsi que sa présence ne sont pas fortuites pour l'acceptabilité de la structure P1 for P2. 


\section{BIBLIOGRAPHIE}

BAUM, L.F. (1995), The Wonderful Wizard of Oz, Penguin Popular Classics

BOUSCAREN, J. et CHUQUET, J. (1987), Grammaire et textes anglais. Guide pour l'analyse linguistique, Gap : Ophrys.

CARROLL, L. (1990), Les aventures d'Alice au Pays des Merveilles / Alice's Adventures in Wonderland, éditions bilingue, Livre de Poche.

CHUQUET, J. (1984), « IF ... » in BOUSCAREN, J., Cahiers de recherche, tome 2, Paris : Ophrys, 45-87.

CULIOLI, A. (1985), Transcription du Séminaire de DEA, Paris VII, D.R.L. et Poitiers.

CULIOLI, A. (1990), Pour une linguistique de l'énonciation. Opérations et représentations, Tome 1, Gap : Ophrys

CULIOLI, A. (1992), « De la complexité en linguistique » in Le gré des langues, L'harmattan.

DE COLA-SEKALI, M. (1991), Connexion inter-énoncés et structuration des relations temporelles et argumentatives en anglais contemporain. Une étude énonciative des connecteurs polyvalents SINCE et FOR, Thèse, Paris III.

DELECHELLE, G. (1989), l'expression de la cause en anglais contemporain, thèse de doctorat, université de Paris III.

FRANCKEL, J. J. et PAILLARD, D. (1991), « Discret - Dense - Compact : vers une typologie opératoire » in FUCHS, C. (ed.) Les typologies de procès, Paris : Klincksieck, 103-136.

FRANCKEL, J.J. \& LEBAUD, D. (1990), Les figures du sujet, Gap : Ophrys.

HOFLAND, K. \& JOHANSSON, S. (1991), Icame Collection of English Corpora, Norwegian Center for the Humanities, Bergen.

KIPLING, R. (1994), The Jungle Books, Penguin Popular Classics.

MELIS, G. (2007), « La coordination inter-propositionnelle » in Rousseau, A., Begioni, L. , Quayle, N. et Roulland, D. (eds) La coordination, Presses Universitaires de Rennes, 141-150.

QUIRK, R. et al. (1985), A Comprehensive grammar of the English Language, London: Longman.

STEVENSON, R.L. (1995), Treasure Island, Electronic Text Center, University of Virginia Libray (http://etext.lib.virginia.edu/toc/modeng/public/SteTrea.html)

VALLÉE, Michaël (2006), « Les traductions françaises de la conjonction for » in H. Chuquet et M. Paillard (éds) Causalité et contrastivité : études de corpus. Presses Universitaires de Rennes, 169-187.

VALLÉE, Michaël (2003), « Because et for partagent-ils les mêmes propriétés énonciatives ? » in CORELA, Cognition, Représentation, Langage, (http://revue-corela.org), vol. 1, $\mathrm{N}^{\circ} 2$.

VALLÉE, Michaël (2002), « Étude énonciative de for interpropositionnel » in Travaux linguistiques du CERLICO. Morphosyntaxe du lexique - 1 - Catégorisation et mise en discours, $\mathrm{n}^{\circ} 15$, Rennes, Presses Universitaires de Rennes, p. 275-283.

WELLS, H.G. (1999), Electronic Text Center, University of Virginia Library 
(http://etext.lib.virginia.edu/toc/modeng/public/WelWorl.html)

WILDE, O. (1991), 'The Happy Prince', The Complete Illustrated Stories, Plays and Poems of Oscar Wilde, Reed International Book.

WOOD, F.T. (1956), « The Expression of Cause and Reason in Modern English » in Moderna Sprak, $50,431-438$.

WYLD, H. (2001), Subordination et énonciation, cahiers de recherche, numéro spécial, Paris : Ophrys.

\section{NOTES}

1. Cf. Vallée $(2002,2003,2006)$

2. P1 fait référence à la proposition qui précède le marqueur et P2 à celle qui le suit.

3. Mélis $(2007,145)$

4. Wyld $(2001,199)$

5. Voir Quirk et al. (1985), Vallée (2003)

6. Deléchelle $(1989,590)$. C'est nous qui soulignons.

7. De Cola $(1991,178)$. C'est nous qui soulignons.

8. De Cola $(1991,186)$

9. On peut également s'interroger sur la manière dont il faut envisager la présence de P2 par rapport à $\mathrm{P} 1$, dans ce cas, afin de préciser comment il est possible de décrire le caractère nécessaire ou non-nécessaire de $\mathrm{P} 2$.

10. Wood $(1956,436)$. C'est nous qui soulignons.

11. Quirk et al. (1985: 927$)$

12. Ce point ne concerne pas la syntaxe étant donné que la plupart des linguistes ne semblent pas remettre en cause l'idée d'avoir deux assertions distinctes, ce qui, d'ailleurs, conduit bon nombre d'entre eux à classer for parmi les conjonctions de coordination.

13. Pour des raisons de clarté dans l'argumentation, nous ne proposerons que les distributions les plus représentatives de notre corpus ainsi qu'un exemple illustrant chacune d'elles.

14. Ces verbes d'état se réduisent majoritairement à la copule be.

15. Les formes simples sont majoritaires. Toutefois, il est possible de trouver des formes verbales associées au present ou au past perfect.

16. Cf. Franckel et Paillard (1991)

17. Franckel et Paillard $(1991,119)$

18. Culioli $(1990,96-97)$

19. Bouscaren et Chuquet $(1987,12)$

20. Cf. Culioli (1985, 38-40)

21. Il s'agit ici d'une simplification d'écriture. Comme nous allons le voir avec cet exemple, P2 se caractérise par une structure complexe de type IF $\mathrm{P}_{2}, \mathrm{Q}_{2}$ '.

22. Franckel et Lebaud $(1990,223-224)$

23. Cf. également Culioli (1992, 16-19) pour une description du concept d'assertion fictive.

24. Cf. Chuquet (1984, 45-87) pour une analyse détaillée de if.

25. Cf. Vallée (2003)

26. L'hétérogénéité énonciative est, en effet, un cas particulier d'altérité.

27. Il est possible d'observer également des adverbes de modalité qui marquent une altérité énonciative en P1.

28. De Cola $(1991,178)$

29. Ibidem $(1991,182)$ 


\section{AUTEUR}

MICHAËL VALLÉE

Université Pierre et Marie Curie - Paris 6 